\title{
Shostakovich
}

\section{Dmitry Rabinovich}

A critical study by a musicologist, containing biographical material and analysis of all the major works of the celebrated Soviet composer.

\section{Illustrated}

$18 s$.

From all booksellers.

\section{Lawrence \& Wishart}

81 Chancery Lane, London, W.C.2
This is what

Desmond Shawe-Taylor wrote about Tempo in a recent issue of

The Sunday Times:

" "TEMPO is far ahead of its competitors both in format and contents. Freely illustrated with music-type and with photographs, TEMPO specialises in informative articles on modern music, and has made itself as indispensable as THE SCORE"

WHY NOT ADD YOUR NAME TO OUR GROWING LIST OF SUBSCRIBERS?

\section{TEMPO}

\section{Publishers:}

\section{BOOSEY \& HAWKES LIMITED} 295 Regent Street, London, W.r.

\section{Overseas Affiliations:}

PARIS: Boosey \& Hawkes, S.A. 22 Rue d'Anjou, Paris 8.

New York: Boosey \& Hawkes, Inc., 30, West $57^{\text {th }}$ Street, New York 19.

Toronto: Boosey \& Hawkes (Canada) Ltd., 209-2 I 3 Victoria Street.

SydneY: Boosey \& Hawkes (Australia) Ltd., 250, Pitt Street.

Capetown: Boosey \& Hawkes (South Africa) (Pty), Ltd., Sam Newman House, Long St. Buenos Aires: Barry \& Cia, Montevideo 264, Buenos Aires, Argentina.

Bons: Boosey \& Hawkes, G.m.b.H., Kronprinzenstrasse 26, Bonn a. Rh., Germany.

"Tempo" subscriptions may be taken out, or single copies obtained, through any of the above.

Nothing in this magazine may be reproduced without permission

\section{SUMMER SCHODL DF MUSIC}

Director of Music: William Glock Secretary: John Amis

\section{DARTINGTON HALL, DEVON}

JULY 30-AUGUST 27

Artists and Teachers include:
Peter Pears

Bruno Maderna

Ana-Raquel Satre

Luigi Nono

Charles Rosen

Josephine Veasey

Beaux Arts Piano Trio

Juilliard String Quartet

Smetana String Quartet

Melos Ensemblo

New York Pro Musica Ensemble

(Dir. Noah Greenbers)

3d. stomp for illustrated prospectus to 
Recent Compositions ...

\section{Aaron Copland}

\section{PIANO FANTASY (I957)}

for Piano Solo

Price 15s. 6d.

THE TENDER LAND (1957)

Orchestral Suite from the Opera

Full Score 42s. od.

Pocket Score I $5 \mathrm{~s}$. od.

\section{OR CHESTRAL VARIATIONS (I958)}

Full Score 35 s. od.

Pocket Score I 2s. 6d. 


\title{
IGOR STRAWINSKY Recent Works
}

\author{
EPITAPHIUM \\ for Flute, Clarinet and Harp
}

Written in memory of Prinz Max Egon zu Fürstenberg, a patron of the Donaueschingen Festival. First performed there in the Summer of 1959

Price 6s. od.

\section{MOVEMENTS}

$-28$

$$
\text { for Piano and Orchestra }
$$

The first European performance will take place in Cologne on 17 th June, 1960, with Margrit Weber as soloist

Full Score 17s. 6d.

Pocket Score 6s. od.

Reduction for Two Pianos 9s. 6d.

\section{DOUBLE CANON}

Raoul Dufy, in memoriam

$$
\text { for String Quartet }
$$

Received its first performance at Town Hall, New York City, in January this year

Price 6s. od.

\section{HODSEY \& HA WKES}

295 REGENT STREET, LONDON W.I 